\title{
Akibat Hukum Dari Perjanjian Kerja Waktu Tertentu (PKWT) Yang Tidak Dicatatkan Oleh PT. X Surabaya
}

\author{
Teo Titanio Marc Peter \\ Devi Rahayu \\ Fakultas Hukum \\ Universitas Trunojoyo \\ rahayudevi78@yahoo.com
}

\begin{abstract}
Abstrak
Perjanjian kerja yang disepakati oleh para pihak akan melahirkan hubungan kerja yang didalamnya memuat syarat-syarat kerja. Dalam prakteknya perjanjian kerja banyak yang tidak sesuai dengan ketentuan ketenagakerjaan Seperti dalam PT.X yang menerapkan sistem Perjanjian Kerja Waktu Tertentu pada pekerjanya dimana perjanjian kerja waktu tertentu tersebut tidak dicatatkan pada Dinas Tenaga Kerja. Penelitian ini berfokus pada bagaimana pelaksanaan perjanjian kerja pada PT.X Surabaya, dan akibat hukum dari perjanjian kerja waktu tertentu yang tidak dicatatkan. Metode penelitian yang digunakan dalam penelitian ini adalah penelitian hukum empiris dengan pendekatan fakta dan dianalisis secara deskriptif Hasil penelitian menunjukkan bahwa selama ini Perjanjian Kerja Waktu Tertentu yang dilakukan oleh PT. X Surabaya dalam pelaksanaannya tidak sesuai dengan Undang-undang UU 13 Tahun 2013dan Kepmen Nomor 100 Tahun 2004. PT. X melakukan perjanjian kerja waktu tertentu secara terus menerus, melakukan perjanjian kerja waktu tertentu atas pekerjaan yang sifatnya tetap atau terus menerus serta PT. X tidak mencatatkan perjanjian kerja waktu tertentu tersebut kepada Dinas Tenaga Kerja Kota Surabaya. Akibat hukum perjanjian kerja waktu tertentu yang tidak dicatatkan demi hukum berubah menjadi perjanjian kerja waktu tidak tertentu hal ini didasarkan atas Pasal 59 ayat (7) Undang-undang Ketenagakerjaan.
\end{abstract}

Kata Kunci: Perjanjian kerja waktu tertentu, akibat hukum, tidak dicatatkan

\begin{abstract}
The work agreement agreed by the parties will enter into an existing employment relationship. But in practice, many of the work agreements are not in accordance with the law. As in PT.X which applies a Specific Time Work Agreement system to its workers where the specified time employment agreement is not approved by the Manpower Office. This study discusses how to implement a work agreement at PT.X Surabaya. The research method used in this research is empirical legal research with fact research, then the data is analyzed descriptively which gives an explanation of the subject and object of research.The results of the study indicate that so far the Specific Time Work Agreement conducted by PT. X Surabaya in its implementation is not in accordance with Manpower Act and Ministerial Decree Number 100 of 2004 concerning Implementation of Specific Time Work Agreements namely PT. X entered into a continuous time work agreement, entered into a specific time work agreement for work that is still ongoing and PT. X does
\end{abstract}


not comply with a special work agreement for the Surabaya City Manpower Office.

Keywords : Specific Time Work Agreements, Legal Results, Not registered

\section{PENDAHULUAN}

Ketenagakerjaan adalah semua hal yang berhubungan dengan tenaga kerja dalam waktu sebelum bekerja, selama bekerja, dan sesudah masa kerja. Hal ini diatur dalam Pasal 1 ayat (1) Undang-undang Republik Indonesia Nomor 13 Tahun 2003 tentang Ketenagakerjaan. Dalam pasal ini Tenaga Kerja dijamin dan dilindungi Pemerintah Indonesia sebelum, selama, hingga sesudah masa kerjanya. Tenaga Kerja dalam Pasal 1 ayat (2) Undang-undang Republik Indonesia 13 Tahun 2003 tentang Ketenagakerjaan menerangkan bahwa "Setiap individu orang yang mampu melakukan pekerjaan guna untuk menghasilkan barang dan/atau jasa baik untuk memenuhi kebutuhan individu maupun untuk masyarakat atau keluarga." Dalam hal ini tenaga kerja mendapatkan upahnya dari pemberian pihak yang dikatakan sebagai pemilik perusahaan atas jasa yang dilakukan pekerja kepada pihak yang memberikan pekerjaan atau yang memerintahnya dalam hal ini sebagai hubungan kerja antara Pengusaha dengan orang yang diberi pekerjaan atau dapat disebut sebagai Pekerja.

$$
\text { Iman Soepomo mengatakan }
$$
bahwa, Hubungan antara pengusaha dan pekerja yang mana pekerja bersedia menyanggupi untuk bekerja kepada pengusaha sehingga mendapatkan upah dan pengusaha juga bersedia menyanggupi untuk membayar upah para pekerja atas pekerjaan yang dilakukan. ${ }^{1}$ Hal ini disebut dengan Hubungan Kerja. Hubungan Kerja terjadi karena adanya Perjanjian Kerja antara pengusaha dan pekerja, yang mana Perjanjian Kerja dapat dibuat secara Tertulis ataupun Lisan. Namun pada Pasal 51 Ayat (2) mengatakan bahwa Perjanjian Kerja yang dipersyaratkan secara tertulis harus dilaksanakan sesuai dengan ketentuan peraturan perundangundangan yang berlaku sehingga antara pengusaha dan pekerja ini menimbulkan hubungan kerja, dan perjanjian kerja harus dibuat atas dasar kesepakatan kedua belah pihak, kemampuan atau kecakapan melakukan perbuatan hukum, adanya pekerjaan yang diperjanjikan, dan pekerjaan yang diperjanjikan tidak bertentangan dengan ketertiban umum, kesusilaan, dan peraturan perundangundangan yang berlaku.

Hubungan kerja adalah hubungan perdata yang didasari oleh kesepakatan kedua belah pihak yaitu antara Pengusaha dan pekerja. ${ }^{2}$ Perjanjian kerja adalah bukti bahwa Pekerja melakukan pekerjaan pada Pengusaha sehingga didalam perjanjian kerja tersebut termuat Hak dan Kewajiban dari masing-masing untuk pengusaha dan pekerja. Di dalam ketenagakerjaan, perjanjian kerja memiliki 2 konsep, yaitu Perjanjian Kerja Waktu Tertentu (PKWT) dan

${ }^{1}$ Iman Soepomo, Pengantar Hukum Perburuhan, Jakarta, Djambatan, 1992, hlm. 52.

2 Khairani, Kepastian Hukum Hak Pekerja Outsourcing, Jakarta, Raja Grafindo Persada, 2016, hlm. 63. 
Perjanjian Kerja Waktu Tidak Tertentu (PKWTT).

Perjanjian Kerja Waktu Tertentu (PKWT) Menurut Pasal 59 Ayat 1 Menjelaskan bahwa "perjanjian kerja untuk waktu tertentu hanya dapat dibuat untuk pekerjaan tertentu yang menurut jenis dan sifat atau kegiatan pekerjaannya akan selesai dalam waktu tertentu."

Selanjutnya pengaturan lain berhubungan dengan Perjanjian Kerja Waktu Tertentu diatur dalam peraturan menteri lebih lanjut yaitu Keputusan Menteri Tenaga Kerja dan Transmigrasi Nomor 100 Tahun 2004, Pasal 13 Menjelaskan bahwa "PKWT wajib dicatatkan oleh pengusaha kepada instansi yang bertanggung jawab di bidang ketenagakerjaan kabupaten/kota setempat selambatlambatnya 7 hari kerja sejak penandatanganan." Namun yang jadi masalah, ketika PKWT tersebut tidak dicatatkan maka didalam Pasal tersebut tidak diterangkan bahwa jika Pengusaha tidak mencatatkan PKWT tersebut tidak ada akibat hukum yang diterima oleh pengusaha. Di dalam praktiknya banyak perusahaan yang memanfaatkan celah tersebut, seperti halnya yang terjadi pada PT. X yang bergerak dalam bidang Manufacture, masih ada pegawai PKWT yang tidak di catatkan kepada Dinas Tenaga Kerja, padahal sudah melewati masa 7 hari kerja sejak penandatanganan.

Berdasarkan hal-hal yang sudah dipaparkan, maka penyusun berkeinginan untuk melakukan penelitian mengenai Perjanjian Kerja yang berjudul "Akibat Hukum Perjanjian Kerja Waktu Tertentu yang Tidak Dicatatkan pada PT. X Surabaya".

\section{METODE PENELITIAN}

Penelitian ini merupakan penelitian hukum empiris, yang menggunakan pendekatan fakta (fact approach), sumber data yang digunakan dalam penelitian ini adalah Data Primer dan Sekunder, yaitu Primer yaitu data yang didapatkan secara langsung pada masyarakat. ${ }^{3}$ Lalu data sekunder dalam penelitian hukum empiris adalah data yang diperoleh dari hasil telaahan studi kepustakaan atau penelahaan dari berbagai literatur yang berhubungan dengan masalah penelitian. ${ }^{4}$ Teknik Pengumpulan Data yang digunakan dalam penelitian ini yaitu Wawancara dan Studi Pustaka, lalu data tersebut di analisis Berdasarkan sifat dari penelitian ini yang menggunakan metode penelitian dengan memberikan penjelasan atau uraian atas subjek dan objek penelitian. ${ }^{5}$ Atau dapat disebut metode penelitian secara deskriptif.

\section{HASIL DAN PEMBAHASAN}

Pelaksanaan Perjanjian Kerja Waktu Tertentu (PKWT) pada PT. X Surabaya

Perjanjian Kerja dibuat atas dasar kesepakatan dari pengusaha dengan pekerja yaitu dengan pekerja mengikatkan diri kepada pengusaha dengan adanya perjanjian kerja tersebut maka hubungan kerja antara pengusaha dan pekerja dapat dimulai. ${ }^{6}$ Pasal 53 Undang-undang Nomor 13 Tahun 2003 tentang Ketenagakerjaan

\footnotetext{
${ }^{3}$ Mukti Fajar dan Yulianto Achmad, Dualisme Penelitian Hukum Normatif \& Empiris, Yogyakarta, Pustaka Pelajar, 2013. hlm. 156.

${ }^{4}$ Ibid, hlm. 156.

${ }^{5}$ Ibid, hlm. 183.

${ }^{6}$ Lihat Pasal 50 ayat (1) Undangundang Nomor 13 Tahun 2003 tentang Ketenagakerjaan
} 
mengatur bahwa Segala hal dan biaya untuk pelaksanaan pembuatan perjanjian kerja tersebut dilaksanakan oleh pengusaha dan menjadi tanggung jawab pengusaha.

Perjanjian kerja adalah perjanjian antara pekerja dan pengusaha atau pemberi kerja yang memuat syaratsyarat kerja, hak, dan kewajiban para pihak. Hal ini diatur didalam Pasal 1 angka 14 Undang-undan-undang Ketenagakerjaan. Perjanjian secara umum diatur didalam Pasal 1320BW, dimana perjanjian kerja tersebut pada umumnya harus memenuhi syarat sahnya sebuah perjanjian, terkait syarat sahnya sebuah perjanjian hal tersebut telah diatur didalam Ketentuan Undang-undang Ketenagakerjaan menjelaskan perjanjian kerja harus dibuat atas dasar kesepakatan kedua belah pihak, kemampuan dan kecakapan untuk melakukan perbuatan hukum, adanya pekerjaan yang diperjanjikan, pekerjaan yang diperjanjikan tidak bertentangan dengan ketertiban umum, kesusilaan dan peraturan perundang-undangan."7

Dalam pembuatan perjanjian kerja hal yang paling utama adalah pengusaha dengan pekerja harus mencapai kata sepakat mengenai hak dan kewajiban pekerja dan pengusaha. Pada proses pembuatan perjanjian kerja, jika pihak pekerja masih ada yang belum mengerti atau masih belum menemukan kesepakatan dengan apa yang diinginkan oleh pengusaha, maka hal tersebut dapat dinegosiasikan terlebih dahulu sampai dengan kesepakatan antara para pihak. Lalu dalam perjanjian kerja, pekerja yang dimaksud disini harus sudah

${ }^{7}$ Lihat Pasal 52 ayat (1) Undangundang Nomor 13 Tahun 2003 tentang Ketenagakerjaan cakap dalam melakukan perjanjian, dimana sudah cakap ini dalam melakukan perjanjian dapat dikatakan pekerja tersebut sudah dewasa menurut hukum. Selanjutnya dalam perjanjian kerja yang tidak kalah penting adalah pekerjaan yang diperjanjikan jelas, dalam hal ini artinya di bagian apa pekerja tersebut bekerja dan pekerjaan yang telah disepakati oleh kedua belah pihak tersebut tidak bertentangan dengan ketentuan undang-undang, khususnya yaitu Ketentuan Undangundang Ketenagakerjaan, karena didalam undang-undang tersebut mengatur mengenai masalah ketenagakerjaan dan peraturan lain tentang perjanjian kerja.

Menurut Undang-undang Nomor 13 Tahun 2003 tentang Ketenagakerjaan, perjanjian kerja dibagi menjadi 2 (dua) macam perjanjian kerja, pembagian ini didasari oleh jangka waktu dari perjanjian kerja tersebut yaitu Perjanjian Kerja Waktu Tertentu (PKWT) dan Perjanjian Kerja Waktu Tidak Tertentu (PKWTT). Perjanjian kerja waktu tertentu adalah perjanjian kerja yang didasarkan oleh jangka waktunya atau selesainya suatu pekerjaan yang ditentukan pada perjanjian kerja. ${ }^{8}$ Sedangkan perjanjian kerja waktu tidak tertentu (PKWTT) atau biasanya dapat disebut pekerja tetap, dimana pekerja tetap ini dibuat atas dasar pekerjaan yang dilakukan secara terus menerus atau tidak terbatas waktu.

Selanjutnya hal tersebut didalam Undang-undang Ketenagakerjaan sudah jelas diatur bahwa perjanjian kerja waktu tertentu (PKWT) hanya

${ }^{8}$ Sendjung Manulang, Pokok-pokok Hukum Ketenagakerjaan Indonesia, Jakarta, PT. Rineka Cipta, 1995, hlm. 69 
boleh dilakukan atas dasar pekerjaan yang sifatnya sekali selesai, pekerjaan yang penyelesaiannya tidak terlalu lama, pekerjaan yang, dan pekerjaan yang berhubungan dengan produk baru hal ini disebutkan pada Pasal 59 ayat (1) Undang-undang Ketenagakerjaan. Dari penjelasan tersebut yang menjadi permasalahan dalam hukum ketenagakerjaan Indonesia, dimana banyak perusahaan yang banyak menerapkan pekerjanya dengan sistem Kontrak/Perjanjian Kerja Waktu Tertentu yang tidak sesuai dengan Pasal $\quad 59 \quad$ Undang-undang Ketenagakerjaan. Seperti contohnya melakukan perjanjian kerja waktu tertentu secara terus menerus, melakukan perjanjian kerja waktu tertentu pada pekerjaan yang sifatnya terus menerus atau tidak musiman.

Mekanisme pembuatan perjanjian kerja diatur di dalam Pasal 54 ayat (1) yang menjelaskan bahwa perjanjian kerja yang dibuat secara tertulis harus sekurang-kurangnya memuat identitas para pihak, jabatan, jenis pekerjaan, besarnya upah, syarat kerja yang memuat hak dan kewajiban pengusaha dan pekerja, tanggal dan jangka waktu perjanjian kerja, tandatangan kedua belah pihak.

Perjanjian kerja yang telah dibuat tersebut pada Pasal 54 ayat (1) huruf e dan $\mathrm{f}$ tidak dapat bertentangan dengan peraturan perusahaan, perjanjian kerja bersama, dan peraturan perundangundangan. Setelah itu perjanjian kerja tersebut dibuat rangkap sekurangkurangnya 2 (dua), yang mempunyai kekuatan hukum sama, serta pekerja/buruh dan pengusaha mendapatkan masing-masing 1 (satu) rangkap perjanjian kerja.

Dalam pembuatan perjanjian ini yang sering terjadi pada sistem hukum ketenagakerjaan yaitu mengenai perjanjian kerja waktu tertentu dan perjanjian kerja waktu tidak tertentu, Pelaksanaan perjanjian kerja seringkali tidak sesuai dengan ketentuan undangundang ketenagakerjaan, masih sering terjadi pelanggaran-pelanggaran yang dilakukan oleh beberapa perusahaan terkait pelaksanaan perjanjian kerja waktu tertentu. Seperti halnya PT. X dalam pelaksanaan perjanjian kerja waktu tertentu yang masih melanggar ketentuan peraturan perundangundangan ketenagakerjaan.

Pelaksanaan perjanjian kerja pada PT. X adalah Perjanjian Kerja Waktu Tertentu (PKWT) dan Perjanjian Kerja Waktu Tidak Tertentu (PKWTT). Yang mana hampir semua jenis pekerjaan yang dilakukan pada PT. X menggunakan sistem PKWT/Kontrak. PT. X masih memiliki 33 9Tiga puluh tiga) pekerja yang masih menggunakan PKWT, pekerja tersebut di tempatkan untuk mengisi pekerjaan antara lain Staff Ticketing, Staff Finance, Staff Umum, Security, Staff Purchasing, Staff Cleaning Service, Berikut penjelasan Andi sebagai Manajer HRD perwakilan Perusahaan pada PT. X mengenai sistem penggunaan PKWT "pada kontrak awal, karyawan akan dikontrak selama 2 tahun, jika sudah 2 tahun maka akan diperpanjang selama 1 tahun."

Terkait pernyataan tersebut bahwa PT. X memberi kontrak/PKWT awal dengan jangka waktu 2 (dua) tahun dan dapat diperpanjang 1 tahun, yang substansinya adalah Tanggal pembuatan perjanjian kerja waktu tertentu dan kesepakatan kedua belah

9 Disarikan dari hasil wawancara dengan Pak Andi sebagai Manajer HRD perwakilan Perusahaan pada PT.X pada tanggal 11 Juni 2020 
pihak untuk melakukan perjanjian, Identitas perusahaan sebagai Pihak I yang berisi tentang nama, jabatan, alamat, pembuatan perjanjian kerja pihak perusahaan di wakili oleh manajer HRD, Identitas pekerja sebagai Pihak II yang berisi tentang nama, NIK, jabatan, atau jenis pekerjaan yang akan diperoleh, dan alamat dari pekerja, Jangka waktu perjanjian kerja waktu tertentu, hal ini memuat menyatakan bahwa perjanjian kerja ini berlaku 2 (dua) tahun, Ketentuan aturan kerja, dalam hal ini memuat tentang aturan kerja, dan hak dan kewajiban antara perusahaan dan pekerja, Jenis Pekerjaan, yang berisi tentang jabatan dan uraian pekerjaan yang dibebankan kepada pekerja, lalu penutup.

Dalam pelaksanaan perjanjian kerja waktu tertentu pada PT. X yang diwakili oleh Pak Andi bagian Manager HRD dengan Pak Aminullah bagian Staff SOP dan Bu Irene bagian Staff Accounting sebagai Pekerja pada PT. X, perjanjian kerja yang dibuat oleh PT. X yang disepakati oleh pekerja, dalam faktanya sesuai dengan Ketentuan Undang-undang Ketenagakerjaan yaitu perjanjian kerja yang dibuat oleh PT. X sesuai dengan Pasal 51 Undang-undang Nomor 13 Tahun 2003 tentang Ketenagakerjaan dimana perjanjian kerja dapat dibuat tertulis maupun lisan, Lalu kenyataannya didalam PT. X menggunakan perjanjian kerja secara tertulis, selanjutnya Pasal 52 Undangundang Nomor 13 Tahun 2003 tentang Ketenagakerjaan dalam hal perjanjian kerja kedua belah pihak sudah setuju untuk mengadakan perjanjian kerja, kemudian pelaksanaan perjanjian kerja tersebut juga sudah sesuai dengan Pasal 54 Undang-undang Nomor 13
Tahun 2003 tentang Ketenagakerjaan dimana perjanjian wajib memiliki identitas kedua belah pihak, jabatan, besarnya upah, serta hak dan kewajiban pengusaha dan pekerja yang semuanya telah ada didalam perjanjian kerja antara perusahaan yang diwakili oleh Pak Andi, dan Pak Aminullah dan $\mathrm{Bu}$ Irene sebagai perwakilan pekerja, selanjutnya Perjanjian kerja yang telah dibuat oleh PT. X menggunakan bahasa Indonesia, dalam hal ini maka sudah sesuai dengan Pasal 57 Undangundang Nomor 13 Tahun 2003 tentang Ketenagakerjaan dimana pasal tersebut menjelaskan tentang perjanjian kerja waktu tertentu harus dibuat dengan bahasa Indonesia dan secara tertulis.

Namun dalam pelaksanaan perjanjian kerja waktu tertentu di PT. $\mathrm{X}$, ditemukan dari hasil wawancara pekerja bahwa masih ada beberapa karyawan di PT. $\mathrm{X}$ yang masih menggunakan sistem kontrak/perjanjian kerja waktu tertentu secara terus menerus, Hal ini sesuai dengan pernyataan Pak Aminullah bagian Staff SOP sebagai Perwakilan Pekerja yang menyatakan bahwa "Saya sudah bekerja selama 6 tahun, akan tetapi sampai sekarang status saya masih karyawan kontrak, namun hal ini tidak hanya terjadi pada saya masih banyak pekerja yang lain juga yang belum tetap namun sudah bekerja ada yang 7 tahun, ada yang lebih dari 10 tahun. "10

Pelaksanaan perjanjian kerja waktu tertentu secara terus menerus tidak sesuai dengan Pasal 59 ayat (4) UU Ketenagakerjaan dimana perjanjian kerja waktu tertentu yang didasarkan dalam jangka waktu

10 Disarikan dari hasil wawancara dengan Pak Amirullah sebagai Pekerja bagian Staff SOP di PT. X pada tanggal 11 Juni 2020 
tertentu paling lama dapat diadakan selama 2 (dua) tahun dan hanya boleh diperpanjang sekali untuk jangka waktu 1 (satu tahun). Dalam hal tersebut pelaksanaan perjanjian kerja waktu tertentu yang dilakukan secara terus menerus oleh PT. X, tidak sesuai dengan jangka waktu yang telah ditetapkan oleh ketentuan ketenagakerjaan. Undang-undang sudah jelas mengatur bahwa perjanjian kerja waktu tertentu tersebut tidak boleh dilakukan secara terus menerus. Ketentuan tersebut juga diatur di Pasal 3 ayat (2) Kepmenakertrans Nomor 100 Tahun 2004 tentang Pelaksanaan Perjanjian Kerja Waktu Tertentu yang mengatur tentang perjanjian kerja waktu tertentu dibuat paling lama 3 (tiga) tahun. Kemudian dalam Pasal 59 ayat (6) Undang-undang Nomor 13 Tahun 2003 tentang Ketenagakerjaan mengatur tentang Pembaharuan perjanjian kerja waktu tertentu dapat dilakukan 1 (satu) kali dalam jangka waktu 2 (dua) tahun, hal ini dapat diadakan sesudah melebihi masa tenggang waktu 30 (tiga puluh) hari berakhirnya perjanjian kerja waktu tertentu yang sebelumnya. Dalam hal ini Pak Aminullah bagian Staff SOP sebagai perwakilan pekerja di PT. X mengatakan bahwa "setelah tiga tahun kontrak saya tidak pernah diliburkan atau di offkan selama 30 hari, saya tetap bekerja sebagaimana mestinya dengan perpanjangan kontrak." "Dari pernyataan tersebut pembaharuan perjanjian kerja waktu tertentu tersebut tidak sesuai dengan ketentuan undangundang ketenagakerjaan, karena pembaharuan tersebut tidak melalui masa tenggang 30 (tiga puluh) hari

11 Disarikan dari hasil wawancara dengan Pak Amirullah sebagai Pekerja bagian Staff SOP di PT. X pada tanggal 11 Juni 2020 sejak dari perjanjian kerja yang lama, hal ini juga terdapat didalam Pasal 3 ayat (6) Kepmenakertrans Nomor 100 Tahun 2004 tentang Pelaksanaan Perjanjian Kerja Waktu Tertentu dimana perjanjian kerja waktu tertentu dilakukan setelah melebihi masa tenggang waktu 30 (tiga puluh) hari sejak berakhirnya perjanjian kerja pertama.

Aminullah sudah bekerja selama 6 (enam) tahun, dimana hal perpanjangan perjanjian kerja waktu tertentu hanya dapat dilakukan sekali selama 1 (tahun) dan pembaharuan perjanjian kerja waktu tertentu hanya dapat dilakukan sekali selama jangka waktu 2 (dua) tahun, dari hal tersebut maka jumlah jangka waktu perjanjian kerja waktu tertentu maksimal adalah 5 (lima) tahun. Sehingga perjanjian kerja tersebut menurut Pasal 59 ayat (7) Undang-undang Nomor 13 Tahun 2003 tentang Ketenagakerjaan bahwasannya "Perjanjian kerja untuk waktu tertentu yang tidak memenuhi ketentuan sebagaimana dimaksud dalam ayat (2), ayat (6) maka demi hukum menjadi perjanjian kerja waktu tertentu (PKWTT)".

Hal demikian juga dibenarkan oleh Pak Rizal bagian Hubungan Industrial, Syarat Kerja (Hubinsyaker), dan Jamsostek bahwa "perjanjian kerja waktu tertentu harus dibuat sesuai dengan peraturan perundangundangan dimana salah satu syaratnya merupakan Pasal 59 ayat (4) adalah jangka waktu perjanjian kerja tersebut tidak boleh melebihi 3 tahun." Sehingga jika PT. X menerapkan sistem perjanjian kerja waktu tertentu/kontrak yang dilakukan secara terus menerus tersebut, maka PT. X menyalahi aturan, oleh karena itu perusahaan yang melakukan perjanjian 
kerja tersebut dengan pekerjanya dengan menerapkan perjanjian kerja waktu tertentu secara terus menerus maka hal demikian tidak dapat dibenarkan.

Selain terkait pelaksanaan perjanjian kerja waktu tertentu secara terus menerus, PT. X juga menerapkan perjanjian kerja waktu tertentu atas pekerjaan yang sifatnya terus menerus, bukan musiman, bukan yang sekali selesai. Salah satu contoh penerapan perjanjian kerja waktu tertentu atas dasar pekerjaan yang sifatnya terus menerus adalah perjanjian kerja waktu tertentu antara perusahaan dan pekerja yakni Irene bagian Staff Accounting, dimana accounting disini adalah pekerjaan yang bukan yang bersifat musiman dan merupakan bagian dari suatu proses dari produksi dalam perusahaan. Tugas Bu Irene sebagai Staff Acounting antara lain Membuat pembukuan kantor, membuat laporan keuangan, membuat neraca laba/rugi, serta membuat laporan pajak. ${ }^{12}$

Didalam Pasal 59 Ayat (1) dan (2) Undang-undang Nomor 13 Tahun 2003 tentang Ketenagakerjaan menjelaskan bahwa perjanjian kerja waktu tertentu hanya dapat dibuat pada pekerjaan yang jangka waktunya tidak lebih dari 3 tahun, dan pekerjaan yang sifatnya musiman atau berhubungan dengan produk baru, lalu perjanjian kerja waktu tertentu tidak boleh diadakan untuk pekerjaan yang bersifat tetap.

Perjanjian kerja waktu tertentu yang dilakukan terhadap $\mathrm{Bu}$ Irene sebagai Staff Accounting jika dikaitkan dengan Pasal 52 ayat (1) Undang-undang 13 Tahun 2003

12 Disarikan dari hasil wawancara dengan Bu Irene sebagai Pekerja bagian Staff SOP di PT. X pada tanggal 11 Juni 2020 tentang Ketenagakerjaan terkait syarat sahnya perjanjian kerja, perjanjian kerja yang dibuat oleh PT. X tidak sesuai dengan apa yang diatur didalam Pasal 59 ayat (1), karena jenis pekerjaan yang dilakukan $\mathrm{Bu}$ Irene sebagai Staff Accounting merupakan pekerjaan yang sifatnya terus menerus. Pasal 52 ayat (3) dimana menyatakan bahwa pekerjaan yang diperjanjikan tidak bertentangan dengan ketertiban umum, kesusilaan, dan peraturan perundang-undangan. Seharusnya perjanjian kerja yang diterapkan adalah perjanjian kerja waktu tidak tertentu. Hal ini juga diatur didalam Kepmenakertrans Nomor 100 Tahun 2004 tentang Pelaksanaan Perjanjian Kerja Waktu Tertentu bahwa perjanjian kerja waktu tertentu hanya bisa diterapkan pada pekerjaan yang sifatnya sekali selesai, musiman, berkaitan dengan produk baru. Maka sesuai dengan syarat sahnya sebuah perjanjian kerja, perjanjian kerja waktu tertentu tersebut batal demi hukum karena melanggar pasal 52 ayat (1) huruf $d$ dimana pekerjaan yang dilakukan oleh $\mathrm{Bu}$ Irene bertentangan dengan undang-undang Pasal 59 ayat (1).

Dalam hal tersebut alasan perjanjian kerja waktu tertentu yang dilakukan secara terus menerus dan pekerjaan sifatnya terus menerus oleh PT. X menurut Pak Andi bagian Manager HRD sebagai perwakilan dari perusahaan PT. X menjelaskan bahwa "karena perusahaan tidak melihat peningkatan performance pekerja tersebut, sehingga perusahaan masih memberi kesempatan untuk pekerja untuk memperbaikinya dengan cara memperpanjang kontrak dia dan akan mengangkat sebagai pegawai tetap jika karyawan tersebut benar-benar 
menunjukan performance yang sesuai KPI (Key Performance Indicator) yang ditetapkan perusahaan.",13

Key Performance Indicator (KPI) merupakan alat bantu manajemen agar suatu kegiatan atau proses dapat diikuti, dikendalikan dan dipastikan untuk mewujudkan kinerja yang dikehendaki. ${ }^{14}$ Oleh karena itu KPI digunakan sebagai metode untuk menilai apa yang dibuat oleh pekerja apakah sesuai dengan apa yang ditetapkan oleh perusahaan. Walaupun perusahaan menerapkan KPI sebagai acuan untuk mengangkat pekerja menjadi pekerja tetap seharusnya perusahaan juga mentaati undangundang bahwa batas jangka waktu maksimal perjanjian kerja waktu tertentu tersebut tidak boleh dilanggar.

Dalam hal perjanjian kerja waktu tertentu, poin pertama yang paling penting atas dibuatnya perjanjian kerja adalah kesepakatan para pihak, Perjanjian kerja waktu tertentu yang dilaksanakan secara terus menerus dan pekerjaan yang sifatnya terus menerus, menurut Ketentuan Undang-undang Ketenagakerjaan memang tidak diperbolehkan karena sudah jelas pada Pasal 59 ayat (7) mengatur bahwa jika melanggar ayat (2) dan (6) maka akibat hukum dari perjanjian kerja tersebut demi hukum berubah menjadi perjanjian kerja waktu tidak tertentu. Akan tetapi kembali lagi dengan syarat

13 Disarikan dari hasil wawancara dengan Pak Andi sebagai Manajer HRD perwakilan Perusahaan pada PT.X pada tanggal 11 Juni 2020

${ }_{14}$ Putri Iglina Lubis dan Ismu Kusumanto, "Penilaian Karyawan Menggunakan Metode Key Performance Indicators (KPI) Studi Kasus CV. Bunda Bakery Pekanbaru”, Jurnal Sains, Teknologi dan Industri, Vol. 15, No. 2, Juni 2018, pp 37 45 sahnya sebuah perjanjian kerja dimana diatur didalam Pasal 52 ayat (1) huruf a bahwa perjanjian kerja didasarkan atas kesepakatan para pihak. Menurut Pak Rizal bagian Kepala Bidang Hubungan Industrial, Syarat Kerja (Hubinsyaker), dan Jamsostek mengatakan bahwa "perjanjian kerja waktu tertentu yang tidak sesuai dengan pasal 59 memang demi hukum akan berubah menjadi pkwtt karena disitu sudah jelas bahwa telah diatur tentang jangka waktu dan jenis pekerjaan perjanjian kerja waktu tertentu, akan tetapi untuk menyatakan hal tersebut pekerja harus melewati prosedur perselisihan hubungan industrial dengan mendalilkan bukti bahwa perusahaan melanggar ketentuan pkwt dalam undang-undang ketenagakerjaan." 15

Sehingga jika pekerja tidak mempermasalahkan hal tersebut kepada perusahaan perjanjian kerja tersebut tetap berjalan, walaupun sebenarnya perjanjian kerja waktu tertentu tersebut tidak sesuai dengan undang-undang. Hal ini karena untuk menyatakan demi hukum menjadi pkwtt atau tidak suatu perjanjian kerja waktu tertentu pekerja harus mengajukan perselisihan hubungan industrial, dimana hal ini adalah perselisihan hak untuk perpindahan status PKWT menjadi PKWTT terkait dilanggarnya Pasal 52 ayat (1) dan Pasal 59 ayat (7) Undang-undang Nomor 13 Tahun 2003 tentang Ketenagakerjaan.

15 Disarikan dari Hasil Wawancara dengan Pak Rizal Zainal Abidin sebagai Kepala Bidang Hubungan Kerja dan Syarat Kerja (Hubinsyaker) dan Jamsostek Dinas Tenaga Kerja Kota Surabaya pada tanggal 24 Juni 2020 
Dalam Pasal 59 ayat (1) jo penjelasan pasal tersebut secara tidak langsung menyatakan bahwa perjanjian kerja waktu tertentu harus dicatatkan kepada Instansi terkait yang bertanggung jawab pada Ketenagakerjaan dalam hal ini adalah Dinas Tenaga Kerja, lalu dalam Pasal 13 Kepmenaker dimana perusahaan yang menerapkan sistem perjanjian kerja waktu tertentu terhadap pekerjanya wajib mencatatkan perjanjian kerja waktu tersebut di Dinas Tenaga Kerja Kabupaten/Kota.

Dalam pelaksanaannya beberapa perusahaan tidak mencatatkan perjanjian kerja waktu tertentu pada Dinas Tenaga Kerja Kabupaten/Kota salah satunya adalah pelaksanaan perjanjian kerja waktu tertentu PT. X, yang juga tidak melaksanakan kewajiban pencatatan perjanjian kerja waktu tertentu pada Dinas Tenaga Kerja Kota Surabaya, Pihak perusahaan berpendapat melalui Pak Andi sebagai Manajer HRD perwakilan Perusahaan pada PT.X bahwasannya "perjanjian kerja waktu tertentu tersebut mengapa tidak dicatatkan ke disnaker karena memang perusahaan sadar bahwasannya beberapa perjanjian kerja waktu tertentu yang dilakukan bertentangan dengan ketentuan peraturan perundang-undangan. Hal ini menjadi percuma jika dicatatkan karena pasti pihak disnaker tidak memberi pengesahan."

Hal ini jelas bertentangan dengan kepmenaker. Perjanjian kerja waktu tertentu yang dibuat PT. X dari mulai awal perjanjian, perpanjangan, dan pembaharuan tidak pernah dicatatkan kepada Dinas Tenaga Kerja Kota Surabaya.
Alasan perusahaan tidak mencatatkan perjanjian kerja waktu tertentu senada dengan pendapat Dinas Tenaga Kerja Kota Surabaya dimana Pak Rizal sebagai Kepala Bidang Hubungan Industrial, Syarat Kerja (Hubinsyaker) dan Jamsostek menyatakan bahwa :

"proses pengesahan perjanjian kerja waktu tertentu di Dinas Tenaga Kerja Kota Surabaya, pihak disnaker akan memilah dan menganalisa perjanjian kerja waktu tertentu yang akan dicatatkan, apabila perjanjian kerja waktu tertentu tersebut dinilai sudah sesuai dengan undang-undang maka akan disahkan dan diberi nomor pencatatan, namun sebaliknya jika perjanjian kerja waktu tertentu tersebut dinilai bertentangan dengan undang-undang maka akan dikembalikan ke perusahaan dan memberi saran agar perusahaan menerapkan perjanjian kerja waktu tidak tertentu terhadap karyawan.,"16

Proses pencatatan perjanjian kerja waktu tertentu tersebut sesuai dengan Undang-undang karena perjanjian kerja waktu tertentu yang dibuat oleh pengusaha memang harus sesuai dengan Pasal 59 ayat (1) Undangundang Nomor 13 Tahun 2003 tentang Ketenagakerjaan, dimana semua syarat tersebut harus wajib terpenuhi, jika perusahaan membuat perjanjian kerja waktu tertentu tersebut dinilai Dinas Tenaga Kerja belum memenuhi undang-undang maka akan dikembalikan dan diberi kesempatan

${ }^{16}$ Disarikan dari Hasil Wawancara dengan Pak Rizal Zainal Abidin sebagai Kepala Bidang Hubungan Kerja dan Syarat Kerja (Hubinsyaker) dan Jamsostek Dinas Tenaga Kerja Kota Surabaya pada tanggal 24 Juni 2020 
untuk memperbaiki perjanjian kerja tersebut.

Selain alasan tersebut diatas berdasarkan wawancara bersama Pak Andi sebagai Manajer HRD perwakilan Perusahaan pada PT. X sebab-sebab tidak dilakukannya pencatatan perjanjian kerja waktu tertentu juga didasari atas Aturan terkait pencatatan perjanjian kerja waktu tertentu kurang jelas, karena perusahaan sudah pasti akan mengangkat Pekerja sebagai pekerja tetap (PKWTT) apabila dalam masa kontrak pekerja menunjukan kinerja yang baik, lalu lemahnya pengawasan dari lembaga yang berwenang. ${ }^{17}$

Sedangkan menurut Pak Aminullah bagian Staff SOP dan Bu Irene bagian Staff Accounting sebagai pekerja di PT. X, perjanjian kerja waktu tertentu yang tidak dicatatkan yakni sebagian banyak pekerja tidak mengetahui tentang pencatatan perjanjian kerja waktu tertentu, pekerja ada yang mengetahui, namun tidak berani mempertanyakan kepada atasan karena takut di PHK, pekerja bersikap apatis, dan tidak adanya serikat pekerja. $^{18}$

Menurut alasan-alasan diatas, 2 faktor utama yang menjadi penyebab perusahaan tidak mencatatkan perjanjian kerja waktu tertentu, yaitu yang pertama terkait tentang ketidaktahuan pekerja atas pencatatan perjanjian kerja waktu tertentu tersebut, ketidaktahuan pekerja ini

17 Disarikan dari hasil wawancara dengan Pak Andi bagian Manajer HRD dan Perwakilan Pekerja di PT. X Surabaya pada tanggal 11 Juni 2020

18 Disarikan dari hasil wawancara dengan Pak Aminullah bagian Staff SOP dan $\mathrm{Bu}$ Irene bagian Staff Accounting sebagai Pekerja di PT. X Surabaya pada tanggal 11 Juni 2020. banyak dimanfaatkan oleh pihak perusahaan untuk melanggar ketentuan-ketentuan yang mengatur tentang perjanjian kerja waktu tertentu tersebut, khususnya terkait dengan kewajiban pencatatan perjanjian kerja waktu tertentu kepada dinas tenaga kerja kabupaten/kota.

Selain hal diatas, ketidaktahuan pekerja dengan kewajiban perusahaan untuk mencatatkan perjanjian kerja waktu tertentu, menandakan bahwa kurangnya sosialisasi dari instansi terkait kepada pekerja/buruh, padahal pengetahuan pekerja/buruh sangatlah penting karena bertujuan untuk melindungi hak-hak pekerja/buruh tersebut. Tidak adanya serikat pekerja juga merupakan suatu faktor yang penting karena tujuan serikat pekerja tersebut adalah memberikan perlindungan, dan pembelaan hak dan kepentingan, serta juga meningkatkan kesejahteraan pekerja beserta keluarganya. ${ }^{19}$

Faktor yang kedua adalah lemahnya pengawasan terhadap perusahaan terkait pelaksanaan kewajiban pencatatan perjanjian kerja waktu tertentu merupakan perhatian penting dalam aspek penegakan hukum pada bidang ketenagakerjaan, Dalam bidang pengawasan, kurangnya kualitas dan kuantitas sumber daya manusia (pengawas ketenagakerjaan) di Dinas Tenaga Kerja merupakan salah satu faktor lemahnya pengawasan dalam pelaksanaan perjanjian kerja waktu tertentu. Sementara itu dalam pelaksanaan pengawasan seharusnya disesuaikan dengan ketentuan pasal 134 Undangundang Nomor 13 Tahun 2003 tentang

${ }^{19}$ Lihat Pasal 4 ayat (1) Undangundang Nomor 21 Tahun 2000 tentang Serikat Pekerja 
Ketenagakerjaan yang menyebutkan bahwa "Dalam mewujudkan pelaksanaan hak dan kewajiban pekerja/buruh dan pengusaha, pemerintah wajib melaksanakan pengawasan dan penegakan peraturan perundang-undangan"

Hal ini juga diakui oleh Pak Andi sebagai Manajer HRD perwakilan Perusahaan pada PT. X yang menyatakan bahwa, "banyak perusahaan tidak mencatatkan perjanjian kerja waktu tertentu karena lemahnya pengawasan dari instansi terkait, ditambah dengan ketidaktahuan pekerja dalam pelaksanaan pencatatan perjanjian kerja waktu tertentu.",20

\section{Akibat Hukum dari Perjanjian Kerja Waktu Tertentu yang Tidak Dicatatkan}

Dinas Tenaga Kerja adalah instansi pemerintah yang bertanggung jawab pada bidang ketenagakerjaan, kewenangan Dinas Tenaga Kerja Kota Surabaya didalam perjanjian kerja waktu tertentu secara tidak langsung diatur dalam Penjelasan Pasal 59 ayat (1) yang mengatakan bahwa "perjanjian kerja waktu tertentu tersebut dicatatkan ke instansi yang bertanggung jawab pada bidang ketenagakerjaan", selain pada Penjelasan tersebut secara langsung kewenangan Dinas Tenaga Kerja Kota Surabaya juga diatur dalam Kepmenaker Pasal 13 yang mana menjelaskan bahwa "PKWT wajib dicatatkan oleh pengusaha kepada instansi yang bertanggung jawab di bidang ketenagakerjaan

${ }^{20}$ Disarikan dari Hasil wawancara dengan Pak Andi sebagai Manajer HRD perwakilan Perusahaan pada PT.X tanggal 11 Juni 2020 kabupaten/kota setempat selambatlambatnya 7 (tujuh) hari sejak penandatanganan.,"2

Hal tersebut juga dikatakan oleh Pak Rizal sebagai Kepala Bidang Hubungan Kerja, Syarat Kerja (Hubinsyaker) dan Jamsostek bahwa "kewenangan disnaker secara tidak langsung disebutkan pada penjelasan pasal 59 ayat (1), selain itu diatur lebih lanjut pada Kepmenaker Nomor 100 Tahun 2004 Pasal 13 yang mana secara langsung kewenangan disnaker disebutkan dalam hal pencatatan perjanjian kerja waktu tertentu,"22

Selain pencatatan perjanjian kerja waktu tertentu yang secara langsung disebutkan pada Kepmenaker tersebut, Dinas tenaga kerja juga berwenang untuk meneliti isi dari perjanjian kerja waktu tertentu tersebut, hal ini disampaikan oleh Pak Rizal sebagai Kepala Bidang Hubinsyaker dan Jamsostek yaitu "Dinas tenaga kerja juga berwenang untuk mengecek dan meneliti apakah perjanjian kerja tersebut sudah sesuai dengan syarat kerja yang telah diatur dalam peraturan perundang-undangan. ,23

Dinas Tenaga Kerja dalam kewenangan pelaksanaan perjanjian kerja waktu tertentu secara tidak langsung diatur di dalam Undang-

21 Lihat Pasal 13 Kepmenakertrans Nomor 100 Tahun 2004 tentang Pelaksanaan Perjanjian Kerja Waktu Tertentu

22 Disarikan dari hasil wawancara dengan Pak Rizal Zainal Abidin sebagai Kepala Bidang Hubungan Industrial dan Syarat Kerja (Hubinsyaker) dan Jamsostek Dinas Tenaga Kerja Kota Surabaya pada tanggal 24 Juni 2020

23 Disarikan dari hasil wawancara dengan Pak Rizal Zainal Abidin sebagai Kepala Bidang Hubungan Industrial dan Syarat Kerja (Hubinsyaker) dan Jamsostek Dinas Tenaga Kerja Kota Surabaya pada tanggal 24 Juni 2020 
undang Nomor 13 Tahun 2003 Tentang Ketenagakerjaan Pasal 59 ayat (1) tersebut memiliki penjelasan yang mana perjanjian kerja waktu tertentu tersebut harus dicatatkan pada Instansi yang bertanggung jawab pada bidang ketenagakerjaan. Selanjutnya pelaksanaan perjanjian kerja waktu tertentu diatur lebih lanjut pada Kepmenakertrans, dimana secara langsung Dinas Tenaga Kerja disebutkan dalam Pasal 13 yang menjelaskan bahwa perjanjian kerja waktu tertentu tersebut wajib dicatatkan pada Dinas Tenaga Kerja dengan jangka waktu maksimal 7 (tujuh) hari sejak penandatanganan, maka dari penjelasan diatas kewenangan Dinas Tenaga Kerja dalam pelaksanaan perjanjian kerja waktu tertentu adalah sebagai pihak pencatatan perjanjian kerja waktu tertentu antara pengusaha dengan pekerja.

Kemudian Dinas Tenaga Kerja juga berwenang mengecek dan meneliti perjanjian kerja waktu tertentu tersebut, apakah perjanjian kerja waktu tertentu tersebut sudah memenuhi ketentuan perundang-undangan yang diatur dalam Pasal 54 Undang-undang Nomor 13 Tahun 2003 tentang Ketenagakerjaan, namun menurut pak Rizal sebagai Kepala Bidang Hubungan Industrial, Syarat Kerja (Hubinsyaker), dan Jamsostek bahwa "akan lebih bagus jika perjanjian kerja tersebut lebih bagus daripada ketentuan undang-undang." 24 Yang dimaksud dari lebih bagus dari

24 Disarikan dari hasil wawancara dengan Pak Rizal Zainal Abidin sebagai Kepala Bidang Hubungan Industrial dan Syarat Kerja (Hubinsyaker) dan Jamsostek Dinas Tenaga Kerja Kota Surabaya pada tanggal 24 Juni 2020 ketentuan undang-undang tersebut salah satunya adalah jika pekerja diberi upah yang melebihi batas upah minimal yang ditetapkan oleh peraturan perundang-undangan.

Jenis-jenis pekerjaan PKWT telah di jelaskan pada Pasal 59 ayat (1) Undang-undang Nomor 13 Tahun 2003 tentang Ketenagakerjaan, Namun dalam proses pencatatan PKWT kepada Dinas Tenaga Kerja Kota Surabaya menurut Pak Imam bagian Staff Hubungan Kerja, Syarat Kerja (Hubinsyaker). dan Jamsostek, perjanjian kerja waktu tertentu dapat dibedakan menjadi 2 (dua) macam, yaituPerjanjian kerja waktu tertentu (PKWT) yang dibuat langsung dari perusahaan terkait dan Perjanjian kerja waktu tertentu (PKWT) yang dibuat oleh pihak pemborongan pekerjaan/penyedia jasa pekerja (outsourcing).

Hal tersebut di golongkan karena terkait persyaratan yang harus dipenuhi untuk pencatatan perjanjian kerja waktu tertentu, yang mana persyaratan tersebut dapat diakses pada Surabaya Single Window, yaitu Surat permohonan yang dibuat oleh direktur perusahaan atau pejabat perusahaan yang mendapat penugasan dari direktur, surat keterangan domisili perusahaan, wajib lapor ketenagakerjaan di perusahaan, bukti kepesertaan dan pembayaran BPJS Ketenagakerjaan dan BPJS Kesehatan, ketentuan/penetapan struktur dan skala upah, PKWT yang telah di tandatangani para pihak sejumlah yang di mohonkan untuk dicatatkan, Bagi perusahaan penyediaan jasa pekerja/perusahaan penerima pemborongan pekerjaan harus melampirkan foto copy : "perjanjian penyediaan jasa pekerja/perjanjian 
pemborongan pekerjaan dan bukti pendaftaran perjanjian penyediaan jasa pekerja/perjanjian pemborongan pekerjaan", soft file Kartu Tanda Penduduk (KTP) Direktur (bagi penduduk non Surabaya), daftar karyawan penduduk kota Surabaya (mencantumkan nama, alamat, NIK). $" 25$

Perbedaan di dalam persyaratan tersebut, jika perjanjian kerja waktu tertentu yang dibuat oleh pihak pemborongan kerja/penyedia jasa pekerja (outsourcing) maka persyaratan tersebut wajib dipenuhi semua, sedangkan untuk perjanjian kerja waktu tertentu yang secara langsung dibuat oleh pihak perusahaan tidak perlu menyertakan lampiran foto copy perjanjian penyedia jasa pekerja/perjanjian pemborongan pekerjaan dan bukti pendaftaran perjanjian penyediaan jasa pekerja/perjanjian pemborongan pekerjaan tersebut.

Pencatatan tersebut dapat diwakilkan oleh pihak lain, dengan menyerahkan Surat Kuasa atau surat penugasan dari direktur dari perusahaan terkait dan Foto copy KTP pihak yang mendapatkan kuasa atau penugasan dari direktur. Selain itu perjanjian kerja waktu tertentu (PKWT) harus pekerjaan yang penempatannya pada kota Surabaya, jika penempatan kerja di kota lain, maka pkwt tersebut tidak dapat dicatatkan.

Dalam pencatatan perjanjian kerja waktu tertentu pada Dinas Tenaga Kerja Kota Surabaya tersebut dilakukan secara Online, yang mana pihak pengusaha hanya mengisi form

\footnotetext{
${ }^{25}$ Pencatatan Perjanjian Kerja Waktu Tertentu (PKWT), ssw.surabaya.go.id, diakses pada tanggal 14 Juni 2020 pukul 23:53
}

pada website ssw.surabaya.net, hal tersebut bertujuan agar memudahkan proses pencatatan dan dapat dilakukan secara efisien, dalam persyaratanpersyaratan tersebut wajib dipenuhi, karena hal tersebut terkait dengan Nomor Pencatatan, yang mana nomor pencatatan tersebut menjadi bukti sah bahwa perusahaan telah mencatatkan pada Dinas Tenaga Kerja Kota Surabaya. $^{26}$

Pencatatan Perjanjian kerja waktu tertentu memiliki tujuan, antara lain untuk memberi perlindungan hak-hak para pekerja secara preventif, yang artinya sebelum kontrak di tandatangani oleh pekerja seharusnya pekerja sudah mendapat perlindungan hukum dari Dinas Tenaga Kerja dalam hal ini sebagai instansi yang bertanggung jawab pada ketenagakerjaan guna untuk memastikan bahwa perjanjian kerja waktu tertentu tersebut tidak melanggar ketentuan yang berlaku. ${ }^{27}$ Pekerja berhak mengetahui hal tersebut, namun menurut Pak Aminullah sebagai Pekerja bagian Staff SOP pada PT. X, tidak tahu mengenai pencatatan PKWT/Sistem kerja kontrak kepada Dinas Tenaga Kerja Kab/Kota, hal tersebut membuat pekerja tidak mendapatkan hak-hak yang mana hak untuk mendapatkan perlindungan secara preventif dari perjanjian kerja yang tidak memenuhi ketentuan undang-undang dan tindakan sewenang-wenang oleh perusahaan.

Dalam hal pencatatan perjanjian

${ }^{26}$ Disarikan dari Hasil Wawancara dengan Pak Rizal Zainal Abidin sebagai Kepala Bidang Hubungan Kerja dan Syarat Kerja (Hubinsyaker) dan Jamsostek Dinas Tenaga Kerja Kota Surabaya pada tanggal 24 Juni 2020

${ }^{27}$ Ikhwan Fahrojih, Op Cit, hlm. 63 
kerja waktu tertentu pada PT. X, pihak perusahaan tidak mencatatkan perjanjian kerja waktu tertentu tersebut kepada Dinas Tenaga Kerja Kota Surabaya, yang mana menurut Pak Andi sebagai Manajer HRD perwakilan Perusahaan pada PT. X menjelaskan bahwa "perjanjian kerja waktu tertentu tidak dicatatkan kepada dinas tenaga kerja kota surabaya, karena aturan dari dinas tenaga kerja yang kurang jelas terkait dengan pencatatan perjanjian kerja waktu tertentu (PKWT) lalu perusahaan juga sudah sadar bahwasannya perjanjian kerja waktu tertentu tersebut tidak memenuhi ketentuan undang-undang jadi walaupun dicatatkan perjanjian kerja waktu tertentu tersebut pasti ditolak oleh pihak disnaker. "28

Selain itu dalam hal pencatatan perjanjian kerja waktu tertentu pada PT. $X$ pihak pekerja yaitu Pak Aminullah bagian Staff SOP sebagai Pekerja PT.X menjelaskan bahwa "pekerja tidak tau menau soal pencatatan perjanjian kerja waktu tertentu, yang penting hak-haknya diberikan oleh perusahaan." Dari alasan pekerja tersebut seharusnya pencatatan perjanjian kerja waktu tertentu tersebut juga merupakan hak pekerja untuk mendapatkan perlindungan secara preventif dari perlakuan perusahaan yang tidak sesuai dengan ketentuan perundangundangan.

Pada Kepmenakertrans Pasal 13 sudah jelas bahwa perjanjian kerja waktu tertentu wajib di catatkan pada Dinas Tenaga Kerja, yang mana bahwa perjanjian kerja waktu tertentu tersebut

28 Disarikan dari Hasil wawancara dengan Pak Andi sebagai Manajer HRD perwakilan Perusahaan pada PT.X tanggal 11 Juni 2020 harus dan wajib di catatkan kepada dinas tenaga kerja. Dalam pendapat Pak Andi sebagai Manajer HRD perwakilan dari Perusahaan PT. X yang lain, Perusahaan sudah pasti akan mengangkat Pekerja sebagai pekerja tetap (PKWTT) apabila dalam masa kontrak pekerja menunjukan kinerja yang baik, Selain itu pihak perusahaan juga berpendapat bahwa "karena sebenarnya Perjanjian Kerja yang dibuat ada beberapa yang memang melanggar ketentuan Pasal 59 yakni Perjanjian Kerja Waktu Tertentu yang dilakukan atas pekerjaan yang sifatnya dilakukan secara terus menerus. ,2

Dari pernyataan tersebut menjelaskan bahwa perjanjian kerja yang dibuat oleh perusahaan memang dibuat tidak sesuai dengan Pasal 59 Undang-undang Nomor 13 Tahun 2003 tentang Ketenagakerjaan, hal tersebut terkait dengan produktivitas kerja menurut Pak Andi sebagai Manajer HRD perwakilan Perusahaan pada PT. X, jika karyawan langsung diangkat sebagai pegawai tetap (PKWTT) karyawan tersebut cenderung mengurangi produktivitas kerjanya, sehingga kinerja yang diberikan tidak bisa maksimal.

Selain itu ada upaya lain yang dapat dilakukan oleh perusahaan untuk menanggulangi pekerja yang kinerjanya tidak bagus/tidak sesuai dengan perjanjian kerja adalah dengan merujuk Pasal 161 ayat (1) Undangundang Nomor 13 Tahun 2003 tentang Ketenagakerjaan yang berbunyi "dalam hal pekerja/buruh melakukan pelanggaran ketentuan yang diatur dalam perjanjian kerja, peraturan

29 Disarikan dari hasil wawancara dengan Pak Andi sebagai Manajer HRD perwakilan Perusahaan di PT. X pada tanggal 11 Juni 2020 
perusahaan atau perjanjian kerja bersama, pengusaha dapat melakukan pemutusan hubungan kerja, setelah kepada pekerja/buruh yang bersangkutan diberi suart peringatan pertama, kedua, dan ketiga secara berturut-turut. ",30

Alasan perusahaan tersebut tidak dibenarkan untuk melakukan perjanjian kerja waktu tertentu yang tidak sesuai dengan peraturan perundang-undangan, karena dalam undang-undang sudah jelas bahwasannya perusahaan dapat melakukan pemutusan hubungan kerja jika kinerja pekerja tidak baik atau pekerja melakukan kesalahan dengan memberikan karyawan surat peringatan pertama, kedua, dan ketiga.

Perjanjian Kerja Waktu Tertentu (PKWT) harus dibuat secara tertulis, karena terkait ketentuan yang telah diatur pada Pasal 57 ayat (1), Setelah itu jika perusahaan dan pekerja setuju dengan perjanjian kerja tersebut maka pekerja akan menandatangani perjanjian kerja, lalu secepatnya perjanjian kerja waktu tertentu tersebut harus segera di catatkan kepada Instansi yang bertanggung jawab pada bidang ketenagakerjaan, artinya perjanjian kerja waktu tertentu yang telah disepakati oleh pengusaha dan pekerja/buruh tersebut harus dicatatkan selambat-lambatnya 7 (tujuh) hari kerja sejak penandatanganan perjanjian kerja tersebut pada instansi terkait yaitu Dinas Tenaga Kerja Kota/Kab setempat domisili dari perusahaan tersebut.

Selanjutnya Pak Rizal menyatakan bahwa "perjanjian kerja waktu tertentu yang tidak di catatkan demi

\footnotetext{
${ }^{30}$ Lihat Pasal 161 ayat (1) Undangundang Nomor 13 Tahun 2003 tentang Ketenagakerjaan
}

hukum berubah menjadi perjanjian kerja waktu tidak tertentu (PKWTT)." Hal tersebut terkait dengan penjelasan Pasal 59 ayat (1) yang mana perjanjian kerja waktu tertentu harus dicatatkan pada instansi terkait yang bertanggungjawab pada bidang ketenagakerjaan kab/kota menurut Pak Rizal, hal tersebut juga merupakan salah satu syarat sahnya sebuah perjanjian kerja waktu tertentu.

Jika perjanjian kerja waktu tertentu tersebut tidak dicatatkan, maka otomatis akan berlaku Pasal 59 ayat (7) Undang-undang Nomor 13 Tahun 2003 tentang Ketenagakerjaan bahwa perjanjian kerja waktu tertentu yang tidak memenuhi ketentuan Pasal 59 ayat (1), ayat (2), ayat (4), ayat (5), ayat (6) demi hukum menjadi perjanjian kerja waktu tidak tertentu. Terkait dengan pernyataan diatas, perjanjian kerja waktu tertentu yang tidak dicatatkan kepada Dinas Tenaga Kerja Kab/Kota demi hukum berubah menjadi Perjanjian kerja waktu tidak tertentu (PKWTT).

Menurut Pak Rizal sebagai Kepala Bidang Hubungan Industrial, Syarat Kerja (Hubinsyaker) dan Jamsostek mengatakan bahwa "perjanjian kerja waktu tertentu tersebut seharusnya demi hukum berubah menjadi pkwtt, maka upaya yang dapat dilakukan oleh pekerja adalah mengajukan Perselisihan Hubungan Industrial (PHI), untuk memperoleh hak status dari PKWT menjadi PKWTT" "31 Pada pernyataan tersebut perjanjian kerja waktu tertentu tersebut seharusnya

31 Disarikan dari Hasil Wawancara dengan Pak Rizal Zainal Abidin sebagai Kepala Bidang Hubungan Kerja dan Syarat Kerja (Hubinsyaker) dan Jamsostek Dinas Tenaga Kerja Kota Surabaya pada tanggal 24 Juni 2020 
tidak dapat dilaksanakan, namun dalam pelaksanaannya jika pekerja tidak melakukan upaya perselisihan hubungan industrial (PHI) perjanjian kerja tersebut tetap dilaksanakan oleh pihak perusahaan karena lemahnya pengawasan dari Dinas Tenaga Kerja terkait pencatatan perjanjian kerja waktu tertentu tersebut, yang mana Menurut Pak Rizal sebagai Kepala Bidang Hubungan Industrial, Syarat Kerja (Hubinsyaker) dan Jamsostek Dinas Tenaga Kerja Kota Surabaya mengatakan bahwa pengawas hanya memeriksa tentang hak-hak pekerja yang tidak sesuai dengan ketentuan undang-undang.

Kemudian Putusan MK Nomor 6/PUU-XVI/2018 yang menyatakan :

"bahwa selanjutnya Pasal 59 ayat (8) UU 13/2003 menyatakan bahwa halhal lain yang belum diatur dalam pasal ini akan diatur lebih lanjut dengan Keputusan Menteri. Norma ini pada pokoknya telah memberikan pendelegasian kepada Menteri yang kewenanganya berkaitan dengan norma a quo untuk mengatur lebih lanjut mengenai PKWT, dan dengan demikian syarat yang akan diatur oleh Menteri tersebut mengikat pula sebagai syarat PKWT. Terkait dengan hal ini, syarat pencatatan PKWT telah diatur oleh Pasal 13 Keputusan Menteri Tenaga Kerja dan Transmigrasi Nomor KEP.100/MEN/VI/2004, yang menyatakan", "PKWT wajib dicatatkan oleh pengusaha kepada instansi yang bertanggung jawab di bidang ketenagakerjaan kabupaten/kota setempat selambatlambatnya 7 (tujuh) hari sejak penandatanganan". "Dengan adanya Pasal 59 ayat (7) dan ayat (8) UU 13/2003, menurut Mahkamah telah jelas mengenai kewajiban pencatatan
PKWT dan akibat hukum dari tidak tercatatnya PKWT tersebut, yaitu bahwa undang-undang memberikan kewenangan kepada Pemerintah, in casu Menteri yang terkait, untuk mengatur lebih jauh mengenai aturan pelaksanaan terhadap norma a quo, selain itu norma yang ada yaitu Pasal 59 UU 13/2003 termasuk Penjelasannya, telah menjadi dasar yang cukup bahwa PKWT wajib dicatatkan dan tidak dicatatkannya PKWT sampai dengan batas waktu yang telah ditentukan demi hukum berubah menjadi PKWTT.",32

Berdasarkan pembahasan diatas dapat diketahui terkait perjanjian kerja waktu tertentu yang tidak dicatatkan di Dinas Tenaga Kerja merupakan perjanjian kerja waktu tertentu yang melanggar ketentuan peraturan perundang-undangan, untuk menyatakan bahwasannya perjanjian kerja waktu tertentu tersebut tidak sesuai dengan peraturan perundangundangan, ada beberapa proses yang harus dijalankan, yaitu pekerja mengajukan perselisihan hubungan industrial terhadap tidak dicatatkannya perjanjian kerja waktu tertentu, hal ini sesuai dengan pendapat Pak Rizal sebagai Kepala Bidang Hubungan Industrial, Syarat kerja (Hubinsyaker), dan Jamsostek di Dinas Tenaga Kerja yang menyatakan bahwa "secara perundang-undangan pkwt yang tidak dicatatkan memang bertentangan dengan undang-undang karena melanggar pasal 59 ayat (1) jo penjelasan pasal 59 ayat (1) jo Kepmenakertrans pasal 13, akan tetapi untuk membuktikannya, pekerja harus mengajukan perselisihan hubungan industrial terkait perjanjian kerja

32 Putusan Mahkamah Konstitusi Nomor 6/PUU-XVI/2018 
waktu tertentu yang tidak

Perselisihan hubungan industrial terjadi karena adanya sebuah perbedaan pendapat antara pengusaha atau gabungan pengusaha dengan pekerja atau serikat pekerja karena adanya perselisihan mengenai hak, perselisihan mengenai kepentingan, perselisihan pemutusan hubungan kerja, dan perselisihan antar serikat pekerja dalam satu perusahaan. ${ }^{34}$

Menurut pasal 1 ayat (1) Kepmenakertrans "perjanjian kerja waktu tertentu merupakan perjanjian kerja antara pekerja dengan pengusaha untuk mengadakan hubungan kerja dalam waktu tertentu untuk pekerjaan tertentu". Dimana substansi dari perjanjian kerja tersebut salah satunya adalah syarat kerja yang memuat hak dan kewajiban para pihak. Perjanjian kerja waktu tertentu yang tidak dicatatkan jika dikaitkan dengan perselisihan hubungan industrial termasuk perselisihan hak, karena perselisihan hak timbul dari tidak dipenuhinya hak, akibat adanya perbedaan pelaksanaan atau sebuah penafsiran terhadap peraturan perundang-undangan, perjanjian kerja, peraturan perusahaan, atau perjanjian kerja bersama. ${ }^{35}$

Perjanjian kerja waktu tertentu yang tidak dicatatkan kepada Dinas

${ }^{33}$ Disarikan dari Hasil Wawancara dengan Pak Rizal Zainal Abidin sebagai Kepala Bidang Hubungan Kerja dan Syarat Kerja (Hubinsyaker) dan Jamsostek Dinas Tenaga Kerja Kota Surabaya pada tanggal 24 Juni 2020

${ }^{34}$ Lihat Pasal 1 ayat (1) Undangundang Nomor 2 Tahun 2004 tentang Perselisihan Hubungan Industrial

${ }^{35}$ Lihat Pasal 1 ayat (2) Undangundang Nomor 2 Tahun 2004 tentang Perselisihan Hubungan Industrial
Tenaga Kerja bertentangan dengan ketentuan peraturan perundangundangan, hal tersebut jika dikaitkan dengan perselisihan hubungan industrial maka menurut Pasal 1 ayat (2) dimana salah satu unsur perselisihan hak adalah perbedaan pelaksanaan terhadap ketentuan peraturan perundang-undangan. Dari pernyataan tersebut perselisihan terkait perjanjian kerja waktu tertentu yang tidak dicatatkan merupakan perselisihan hak.

Hal ini juga dikatakan oleh pak Rizal sebagai Kepala Bidang Hubungan Industrial, Syarat kerja (Hubinsyaker), dan Jamsostek pada Dinas Tenaga Kerja Kota Surabaya yang menyatakan bahwa "perselisihan tentang perjanjian kerja waktu tertentu yang tidak dicatatkan oleh perusahaan termasuk perselisihan hak karena sudah diatur didalam ketentuan peraturan perundang-undangan bahwa perjanjian kerja waktu tertentu harus dicatatkan. "36

Karena perjanjian kerja waktu tertentu termasuk perselisihan hak, maka upaya yang bisa dilakukan oleh pekerja yang pertama sesuai dengan Pasal 3 Undang-undang Nomor 2 Tahun 2004 tentang Perselisihan Hubungan Industrial yaitu semua upaya perselisihan hubungan industrial wajib diupayakan terlebih dahulu dirundingkan melalui perundingan bipartit, namun jika perundingan tersebut dirasa tidak tercapai kesepakatan, maka dapat dilanjutkan dengan upaya mencatatkan

36 Disarikan dari Hasil Wawancara dengan Pak Rizal Zainal Abidin sebagai Kepala Bidang Hubungan Kerja dan Syarat Kerja (Hubinsyaker) dan Jamsostek Dinas Tenaga Kerja Kota Surabaya pada tanggal 24 Juni 2020 
perselisihan tersebut kepada Dinas Tenaga Kerja dengan memberikan hasil upaya penyelesaian bipartit yang telah dilakukan antara pekerja dengan perusahaan, setelah diterima dan dicatatkan oleh Dinas Tenaga Kerja, maka pekerja dan perusahaan akan diberi kesempatan untuk memilih penyelesaian melalui arbitrase atau konsiliasi, namun jika kedua belah pihak tidak memilih salah satu dari penyelesaian tersebut, maka menurut Pasal 4 ayat (4) Undang-undang Nomor 2 Tahun 2004 tentang Perselisihan Hubungan Industrial mengatakan "bahwa penyelesaian perselisihan tersebut dilimpahkan kepada Mediator dimana pekerja dan pihak perusahaan akan melakukan penyelesaian dengan cara Tripartit/Mediasi." Selanjutnya jika penyelesaian perselisihan tersebut masih dirasa belum menemui kesepakatan, Salah satu pihak dapat mengajukan gugatan kepada Pengadilan Hubungan Industrial hal ini diatur dalam Pasal 5 Undang-undang Nomor 2 Tahun 2004 tentang Perselisihan Hubungan Industrial.

Namun jika pekerja tidak mengajukan perselisihan terkait dengan tidak dicatatkannya perjanjian kerja waktu tertentu, perjanjian kerja tersebut tetap bisa dilaksanakan walaupun perjanjian kerja waktu tertentu tersebut tidak memenuhi ketentuan peraturan perundangundangan yang berlaku.

\section{SIMPULAN}

Pelaksanaan perjanjian kerja waktu tertentu pada PT. X banyak yang masih tidak sesuai dengan ketentuan peraturan perundangundangan yaitu antara lain, perjanjian kerja waktu tertentu yang dilakukan secara terus menerus, perjanjian kerja waktu tertentu yang dilakukan atas dasar pekerjaan yang sifatnya tetap atau terus menerus serta perjanjian kerja waktu tertentu pada PT. X juga tidak dicatatkan kepada dinas tenaga kerja kota surabaya, karena perusahaan menyadari bahwa perjanjian kerja waktu tertentu tersebut tidak sesuai dengan peraturan perundangundangan, lemahnya pengawasan dari pihak berwenang, ketidaktahuan pekerja atas pkwt, ketidakberanian pekerja karena takut di PHK, tidak adanya serikat pekerja, dan sifat apatis dari pekerja. dan Akibat hukum dari perjanjian kerja waktu tertentu yang tidak dicatatkan yaitu demi hukum berubah menjadi PKWTT hal ini didasarkan pada ketentuan Pasal 59 ayat (7), Akan tetapi untuk dinyatakan demi hukum berubah menjadi PKWTT pekerja harus melakukan upaya perselisihan hubungan industrial, jika pekerja tidak melakukan upaya tersebut, maka perjanjian kerja waktu tertentu tersebut masih tetap dapat dilaksanakan walaupun tidak memenuhi ketentuan peraturan perundang-undangan yang berlaku.

\section{DAFTAR RUJUKAN}

\section{Buku}

Bambang, Joni. Hukum Ketenagakerjaan. Bandung. Pustaka Setia. 2013

Fahrojih, Ikhwan. Hukum Perburuhan Konsepsi, Sejarah, dan Jaminan Konstitusional. Jakarta. Setara Press. 2015 
Husni, Lalu. Pengantar Hukum Ketenagakerjaan. Jakarta. Raja Grafindo Persada. 2016

Johan Nasution, Bahder. Metode Penelitian Ilmu Hukum. Bandung. CV Mandar Maju. 2016

Khairani. Kepastian Hukum Hak Pekerja Outsourcing. Jakarta. Raja Grafindo. 2016

Muhammad, Abdulkadir. Hukum dan Penelitian Hukum. Bandung. Aditya Bakti. 2004

Muhammad Rifqi Noval, Sayid. Hukum Ketenagakerjaan Hakikat Cita Keadilan dalam Sistem Ketenagakerjaan. Jakarta. Refika Aditama. 2017

Mukti Fajar dan Yulianto Achmad. Dualisme Penelitian Hukum Normatif \& Empiris. Yogyakarta. Pustaka Pelajar. 2013

Rahayu, Devi. Hukum Ketenagakerjaan Teori dan Studi Kasus. Yogyakarta. New Elmatera, 2011

Soepomo, Imam. Pengantar Hukum Perburuhan. Jakarta. Djambatan. 1992

Uwiyono, Aloysius. Asas-Asas Hukum Perburuhan. Jakarta. Raja Grafindo Raja Grafindo Persada. 2004

Wijayanti, Asri. Hukum Ketenagakerjaan Pasca Reformasi. Jakarta. Sinar Grafika. 2009

\section{Peraturan Perundang-undangan}

Undang-undang Nomor 21 Tahun 2000 tentang Serikat Pekerja
Undang-undang Nomor 13 Tahun 2003 tentang Ketenagakerjaan

Undang-undang Nomor 12 Tahun 2011 tentang Pembentukan Peraturan Perundang-undangan

Undang-undang Nomor 23 Tahun 2014 tentang Pemerintahan Daerah

Peraturan Pemerintah Nomor 18 Tahun 2016 tentang Perangkat Daerah

Keputusan Menteri Tenaga Kerja dan Transmigrasi Nomor 100 Tahun 2004 tentang Ketentuan Perjanjian Kerja Waktu Tertentu

\section{Putusan}

Putusan Mahkamah Konstitusi Nomor 6/PUU-XVI/2018

\section{Sumber Lainnya}

Pencatatan perjanjian kerja waktu tertentu (PKWT) diakses di https://ssw.surabaya.go.id pada tanggal 14 Juni 2020 